\title{
History, Commemoration, and Belief: Abraham Lincoln in American Memory, I945-200I
}

\author{
Barry Schwartz \\ University of Georgia
}

\author{
Howard Schuman \\ University of Michigan
}

\begin{abstract}
Ever since Maurice Halbwachs's pioneering work, most scholars have been content to explore collective memory through texts and commemorative symbolism. Assuming that a study of collective memory has fuller meaning when it takes into account what ordinary people think about the past, we compare historians' and commemorative agents' representations of Abraham Lincoln to what four national samples of Americans believe about him. Five primary images-Savior of the Union, Great Emancipator, Man of the People, First (Frontier) American, and Self-Made Man - are prominent in the cumulative body of Lincoln representations, but recent surveys show that only one of these images, the Great Emancipator, is dominant within the public. Lincoln's one-dimensional Emancipator image, which differs from the multi-dimensional one evident in a 1945 sample, reflects new perceptions of the Civil War shaped by late twentieth-century minority rights movements. Thus, "bringing men [and women] back in" involves survey evidence being added to historiographic and commemoration analysis to clarify one of sociology's most ambiguous concepts, collective memory, and to explore its social and generational roots.
\end{abstract}

$\mathrm{C}$ ollective memory scholarship stands at a turning point. Will the field continue to move in its present direction, emphasizing only "sites" of memory and their cultural meanings, or will it break through to a new level of inquiry, one that includes individuals' beliefs about the past? Four decades ago, George Homans's

Direct correspondence to Barry Schwartz, Department of Sociology, University of Georgia, Athens, GA 30606 (cmsbarry@uga.edu), and Howard Schuman, Department of Sociology, University of Michigan, 255 Popham Road, Phippsburg, Maine 04562 (hschuman@umich.edu). The authors thank the University of Georgia Senior Faculty Research Grants in the Humanities and Fine Arts and the Lady Davis Fellowship Trust, Hebrew University of Jerusalem, for supporting this project. They thank Jeffrey Olick for his many useful comments on an earlier draft. They are grateful to Paul Roman, Director, Center for Research on Deviance, and James J. Bason, Director, Survey Research Center, University of Georgia, for generosity and assistance on their National Employee Survey
(1964) essay, "Bringing Men Back In,” claimed that sociological theory explains nothing if it ignores the individual as agent and subject. For a similar though not identical reason, we ask whether the field of collective memory must now bring people back in, and, if so, how.

\section{WHAT COLLECTIVE MEMORY MEANS}

Maurice Halbwachs founded the field of collective memory, but between 1945, the year of his death, and the early 1980s, American sociologists ignored his work. Lloyd Warner, the only American then addressing collective memory issues (The Living and the Dead, 1959) does not even mention him. After 1980, Halbwachs is cited time and again, even though his two major books, Les Cadres Sociaux de la Mémoire ([1925] 1952) and La Topographie Légendaire des Évangiles en Sainte-Terre (1941), have not been translated into English. (Lewis Coser's translated selections from Halbwachs's collected works - which include research on suicide and stratification-did not appear until 1992). Halbwachs's discoveries did 
not cause the great current of collective memory research beginning in the 1980s; they were swept into it. ${ }^{1}$

Since Halbwachs saw individuals in groups as carriers of collective memory, he would have trouble recognizing the current of research that his name now adorns. Kerwin Klein (2000) criticizes this current with a special term, "The New Structural Memory," which refers not to Halbwachs's claim that social structures affect what individuals remember but that memory is collective only if it exists outside the mind of the individual. Pierre Nora (1996) finds collective memory in sites (lieux de mémoire) that include all material objects representing France's past, independently of their meaning to individual Frenchmen. Richard Terdiman declares that memory resides "not in perceiving consciousness but in the material [symbols and rituals] which do not seem to require either our participation or explicit allegiance" (1993:34). Michael Schudson comes to a similar conclusion: memory consists of the concrete "rules, laws, procedures, precedents, records, files, books, holidays, statues, mementos" (1994:51) of specific institutions ${ }^{2}$ - which conforms to the more abstract proposition that institutions remember (Douglas 1987). Jeffrey Olick dissociates himself from a radically structural approach to memory, but he defines the past represented through sites and symbolic structures as "genuinely collective memory;" the past represented by surveys of individuals constitutes something less: "collected memory" (1999:345). Taking "collective representations" and other "social facts" (Durkheim [1911] 1974:135; [1895] 1964:1-46) as their ultimate units of analysis, many sociologists share Olick's

${ }^{1}$ La Mémoire Collective, a set of essays written by Halbwachs and published by his students in 1950, first appeared in English in 1980 as The Collective Memory under the editorship of Mary Douglas.

${ }^{2}$ Although Schudson's version of the New Structural Memory is influential, he recognizes that these "rules, laws, standardized procedures, and records . . books, holidays, statues, souvenirs" owe their cultural power to their subjective meaning (1989; see also his exemplary essay on the subjective dynamics of memory and its distortion [1996]). On the other hand, Schudson has never explored the relation among subjective dynamics, texts, symbols, and observances. conception. Robert Wuthnow (1987) asserts that we can never know what objects (including history texts and memory sites) mean to individuals; we can only know how these objects relate to one another and to institutional structures. We thus enter a new age in which archives, statues, and other material objects are no longer the instruments but the embodiments of memory (Klein 2000:136). Amos Funkenstein provides the New Structural Memory's most precise formulation:

Collective memory ..., like "language," can be characterized as a system of signs, symbols, and practices: memorial dates, names of places, monuments and victory arches, museums and texts, customs and manners, stereotyped images (incorporated, for instance, in manners of expression), and even language itself. (1993:6)

Funkenstein excludes the individual as an essential unit of collective memory.

To consider the Structural Theory of Memory as a methodological artifact, a remnant of earlier days when measures of beliefs and attitudes were unavailable, is implausible. For more than a quarter-century, such measures have been available by means of surveys, but few collective memory scholars have shown an interest in pursuing survey evidence. Theoretical perspective, not methodological limits, leads these scholars to emphasize hermeneutic analysis of texts and commemorative objects and to deemphasize, even disregard, what ordinary individuals believe about the past. Perspective, not data, causes cultural production to trump cultural reception.

When scholars recognize subjectivity's importance but say nothing concrete about its referents, their comments produce more confusion than clarity. Alon Confino asserts that models excluding the individual have been used "either perfunctorily or as a hollow metaphor defining memory as a monolith" in expressions like "the collective memory of the state" (1997:1386). For Susan Crane, "[A]11 narratives, all sites, all texts remain objects until they are 'read' or referred to by individuals thinking historically" (1997:1381). Fentress and Wickham (1992) say that collective memory theory, when disconnected from the "actual thought processes of any particular person," renders the individual an automaton and therefore reifies the psychological in the social. "Hollow metaphor," "objects," and "automa- 
ton" refer to recollection without meaning. But what of meaning itself? The welter of criticism, plainly, suggests no new research direction. Jeffrey Prager is more specific than most, but no more concrete: "[c]ollective memory is a sociological concept, though shot through with psychological presumptions" about cognitive frames, identity, and trauma (2001:2223). To recognize that collective memory is permeated with psychological presumptions, however, is not necessarily to know how to bring individuals into collective memory scholarship. Noa Gedi and Yigal Elam (1996), in this regard, throw up their hands. "Since only individuals, not groups, can remember, the only proper use of collective memory is a metaphorical one.... 'Collective memory' is but a misleading new name for the old familiar 'myth" "(p. 47). These critical writings identify a basic problem but they define it differently, fail to explain how to solve it, and confuse the issue by taking us in different directions. We intend to move forward by defining collective memory in a way that specifies what we do when we study it, such that we can develop and control new lines of inquiry that explore what individuals believe about the past and relate these beliefs to traditional methods of representing it.

\section{COLLECTIVE MEMORY: HISTORY, COMMEMORATION, AND BELIEF}

In preliterate society, no history exists; oral tradition is expressed in the form of myth and institutionalized through ritual. In modern society, the rich development of historical research and commemorative art makes collective memory more complex. Historical narratives include historiography (research and analytic monographs), public school and college-level textbooks, encyclopedia essays, and, at a more popular level, propositions conveyed through magazines, newspapers, television, film, stage productions, and websites. Commemorative symbolism includes hagiographies (eulogy and ritual oratory), monuments, shrines, relics, statues, paintings, prints, and ritual observances. Because historical and commemorative objects are transmissible, cumulative, and received differently from one group to another, they exert influence in ways difficult to understand solely in terms of their producers' beliefs or personal characteristics.
History and commemoration perform different functions. The job of the historian is to enlighten by revealing causes and consequences of chronologically ordered events. The job of the commemorative agent is to designate moral significance by lifting from the historical record the events that best exemplify contemporary values. Historians aim to describe events in all their complexity and ambiguity; commemorative agents, to simplify events into objects of celebration and moral instruction. History and commemoration, however, cannot be empirically separated. Just as history reflects the values commemoration sustains, commemoration is rooted in historical knowledge. Commemoration is intellectually compelling when it symbolizes values whose past existence history documents; history is morally and emotionally compelling when it documents events that can be plausibly commemorated. ${ }^{3}$

Collective memory realizes itself in distributions of beliefs about the past, but since the relation among beliefs, history, and commemoration is problematic, two clarifications are warranted. First, text writers, symbol makers, and their consumers are all individuals; therefore, one can argue that the key distinction is not cultural memory vs. individual memory, but elite memory vs. popular memory. There is no harm in alternative terminology unless we forget that elite memory's units of analysis - history texts and commemorative symbols - are different from individual memory's units of analysis - personal beliefs. Second, since the meaning of events to individuals reflects objective qualities (described by historians) as well as individuals' experience and perceptual capacities (Griswold 1987b; Fine 1996; Jauss 1982), collective memory cannot be dismissed, as it so often is, as distorted history based on myth, chauvinism, and self-deception

\footnotetext{
${ }^{3}$ History, as Halbwachs ([1950] 1980) defines it, seeks an objective standpoint to assess the sequence, mutual relations, causes, and consequences of past events. It is "situated external to and above groups" and records the past independently of those groups' immediate problems and concerns. Since commemoration is rooted in these problems and concerns, history and commemoration, as Halbwachs sees them, are mutually conflicting enterprises (pp. 80-81; 83-87).
} 
(Nora 1996:1, 7, 8; Wertsch 2002:30-66; Yerushalmi 1982:81-103; Lowenthal 1996:119-122; Kammen 1997:214, 219, 221; Gorn 2000:5B).

\section{PRESENT PROBLEM}

Reception, applied to collective memory, reflects the way individuals process historical and commemorative statements. "Whether the general run of people read history books or not," Carl Becker observes, "they inevitably picture the past in some fashion or other" (Snyder 1958:61). Becker's point reiterates Charles Horton Cooley's dictum that the "imaginations which people have of one another are the solid facts of society" ([1902] 1964:121). The solid facts of memory, likewise, are the imaginations people have of historical events and actors.

Connecting historical and commemorative objects ("facts of representation") to individual understandings of the past ("facts of reception"; Kansteiner 2002:179) raises four major questions never before posed or addressed: (1) How far, if at all, do individual beliefs deviate from historical and commemorative statements? (2) Do historical and commemorative statements change at the same rate and in the same direction as individual beliefs? (3) How and to what extent do individual beliefs, historical texts, and symbolic representations affect one another? (4) Which aspects of late twentieth-century American society do such beliefs, texts, and representations articulate?

Whether new historical interpretations reflect discovery of new data, emphasis on one facet of a multifaceted personality, policy, or projection of present social issues upon a distant past, is an important question. It makes a difference whether historical accounts are empirically sound, exaggerated, selective, or invented - but to assess this difference is not our problem. The relationships among history, commemoration, and individual belief, not their validity, concern us here.

Good answers to any question benefit from a good specimen. No American's life has been documented more fully, commemorated more often, and admired more intensely than Abraham Lincoln's. As "Lincoln is the supreme myth, the richest symbol in the American experience" (Rossiter 1960:108), his story is an essential part of the story of American "peoplehood" (Smith 2003). Lincoln's life embodies America's story because it personifies egalitarianism, populism, libertarianism, and individualism - the core values of American political culture (Lipset 1996:19-23; see also Lipset 1990; Schwartz 2000). If Lincoln were removed from this story, its moral content would be less moving, less powerful; its moral essence less compelling. Lincoln is ideal for studying American memory because he remains a prophet of American civil religion (Bellah 1976:177-78), American equality (Wills 1992), and is central to the American people's changing self-definition.

\section{FIVE LINCOLNS}

Merrill Peterson's (1994) Abraham Lincoln in American Memory is by far the most comprehensive and authoritative chronicle of Lincoln representations. Incorporating but transcending typologies constructed independently by Basler (1935), Wector (1941), Donald (1947), and Potter (1948), Peterson draws out five images from a 138-year series of Lincoln histories, biographies, monuments, shrines, icons, place names, and ritual observances:

1. "Savior of the Union" refers to objects that express Lincoln's belief in the indivisibility of the American state.

2. "The Great Emancipator" represents Lincoln's efforts to abolish slavery.

3. "Man of the People" reflects writings and commemorative devices depicting Lincoln's identification with ordinary Americans.

4. "The First American" is Lincoln the frontier youth, symbolized by log cabins and axes and highlighting a personality that combines folksiness with dignity and vulgarity with kindness.

5. "The Self-Made Man" refers to Lincoln as the exemplification of upward mobility.

Since each image expresses a different pattern of historical writing and commemoration, Lincoln in American memory, as Peterson conceives it, means Lincoln represented by text and symbol rather than Lincoln as individuals think about him. Peterson nowhere denies that the five Lincolns exist in the minds of individuals, but his account ignores individual beliefs almost entirely. 


\section{LINCOLN IN THE AMERICAN MIND}

Merrill Peterson's account of Lincoln's meaning to America is structural. His vast chronicle of historians, popular writers, painters, sculptors, and monument architects furnishes good examples of "reputational enterprise" (Fine 1996) repetitive representations that "form the backbone of collective memories" (Kansteiner 2002:190). But Peterson's is a descriptive chronicle; while he inventories representations of Lincoln he fails to weight their relative importance, over time or across society. Peterson makes no effort to explain why different agents portray Lincoln in different ways, let alone whether these portrayals conform to popular beliefs - or whether his five Lincolns fully capture them.

We think it useful to examine beliefs directly: not instead of, but in addition to the historiographic and symbolic vehicles traditionally comprising the data of collective memory. By drawing on sample surveys to learn what the American population believes about noted figures like Lincoln, and how closely these beliefs conform to historians' and commemorators' accounts, we move beyond the methodological divide that has for so long limited collective memory research. A broader challenge is to confront the difficulties of melding qualitative and quantitative perspectives and methods. Responses to survey questions are no substitute for descriptions of how narratives and symbols frame individual experience (Swidler 2001; Wertsch 2002), but properly designed surveys can indicate what Americans believe. Most Americans do not spend much time thinking about Lincoln, but they do carry in their minds ideas, characterizations, information (and in some cases misinformation) that surveys can reveal. And since our data allow us to see how individuals weigh different strands of discourse, we need not assign to Lincoln's images the equal weights assumed by Peterson and others investigators.

Popular beliefs about Abraham Lincoln reflect the content of texts and commemorative symbols, but popular beliefs reinterpret texts and reinvigorate symbols. As we argue later, Americans' perception of Lincoln as a Great Emancipator and early civil rights leader is a social force in its own right. Evidence on individual beliefs is no minor gloss on collec- tive memory but essential to understanding its substance and function.

Because responses to survey questions can vary depending on how questions are framed, we take more than one approach to measuring popular beliefs. Our first inquiry concerns Lincoln as a president; our second, what Lincoln did and how he acted before and after his election to the presidency; our third, introduced at a later point, how different generations compared him to another great president. Each inquiry elicits comparable perceptions, regardless of differences in question wording. ${ }^{4}$

\section{PRESTIGE AND REPUTATION}

Professional historians, regardless of political ideology, consistently assign Lincoln to the top category of presidential prestige, along with George Washington and Franklin Roosevelt (Murray and Blessing 1988; Schlesinger 1997; Lindgren and Calabresi 2000). Only in Lincoln's case, however, does public opinion follow professional opinion. In 1999 we replicated a Gallup question, "Which three United States presidents do you regard as the greatest?"5 by including it in a 1999 National Omnibus Random Digit Dial telephone survey $(\mathrm{N}=$ 1,001) carried out by the University of Maryland Survey Research Center. Lincoln was named most often, by 45 percent of the sample. Kennedy was second (35\%), and the other runners-up were Reagan (29\%), Washington (28\%), Franklin Roosevelt (27\%), and Clinton (24\%). The naming of other presidents then drops off sharply, with Truman next at $12 \%{ }^{6}$

Our next step was to assess the primary content of Lincoln's reputation. Merrill Peterson describes five reputational genres-Savior of the Union, Great Emancipator, Man of the People, First American, and Self-made Manthat have endured since Lincoln's death, but

\footnotetext{
${ }^{4}$ The principle of reading open-ended discourse in the context of prevailing symbolic forms can be central to survey analysis in ways similar to its role in ethnography and depth interviews (Schuman 2003).

${ }^{5}$ Gallup conducted these national surveys in January 1956, November 1975, June 1985, and December 1991.

${ }^{6}$ Percentages exclude "don't know" responses and nonresponses.
} 
since he never ranks them, their equal relevance must be assumed. To test this null hypothesis, we divided the Maryland sample into those who named Lincoln a great president and those who did not, then asked the former, "Why do you think Abraham Lincoln was one of America's three greatest presidents?" To those who did not name Lincoln a great president, interviewers asked a parallel question: "Although you did not mention Abraham Lincoln as one of the three greatest presidents, we would like to know what comes to mind when you think of Abraham Lincoln." Both questions included nondirective follow-up probes ("Can you say a little more about that?") to encourage fuller replies. Before combining the two sets of very similar responses, ${ }^{7}$ we coded up to two responses to the original questions and up to two to the follow-up probes, with 40 percent of the respondents providing more than one distinguishable type of response.

In a second survey, carried out by Knowledge Networks $(\mathrm{N}=1,005)$ between July 13 and July 17,2001 , we used a different question to determine what Americans think about Lincoln: "Suppose a nephew or niece about 12 years old had just heard some mention of Abraham Lincoln and asked you to explain what Abraham Lincoln had done. What would you say?" This question is especially appropriate for investigating collective memory since it focuses on what adults recall as most important about Lincoln to communicate to a younger generation. We coded up to three themes for each respondent.

In sum, respondents answered open questions, expressed their beliefs about Lincoln in their own words, and we subsequently coded their responses into the categories shown in Table 1. The two surveys-referred to as the

\footnotetext{
${ }^{7}$ We merged Maryland responses of those who had named Lincoln a great president and those who had not. There were few differences between the two distributions, though those not naming Lincoln "great" were more apt to say "don't know" when asked to speak further about him (11\% vs. 3\% of those calling him great), and all negative responses reported come from such respondents. Those not naming Lincoln great were also less likely to give a Union response, though equally likely to mention Emancipation.
}

Maryland and Knowledge surveys - were different in the questions they asked, one focusing on the man and the other on what he had done (and the Maryland survey used two slightly different questions depending on whether Lincoln was initially named or not named as great); in their modes of administration (telephone vs. Internet); in their sample response rates and likely sources of sample bias; in their dates; and in the organizations administering them (see Appendix A on ASR online supplement, http://www.asanet.org/journals/asr/2005/toc044. $\mathrm{html})$. These differences in question form and sampling could be expected to produce some differences in results, but we found important consistencies.

Our initial categories were designed to fit the five Peterson themes listed previously, but we included additional categories to accommodate other reasons that appeared in a preliminary subsample of responses. The "First Mentions" columns in Table 1 report the initial responses given in each survey. Since such answers are mutually exclusive, they total 100 percent when the miscellaneous "Other Positive Beliefs" are included. The "Any Mentions" columns allow for coding multiple responses given to a question and thus use all the answers; they are not mutually exclusive because a respondent may have mentioned several codable themes. The two types of coding yield similar patterns, not surprising since the bulk of the "Any Mentions" are "First Mentions." We focus on "Any Mentions" in our following discussion.

\section{EPIC THEMES}

Peterson's five Lincolns, understood through common educational experience, constitute "social types" (Schutz 1970:116-22; see also Klapp 1962; Berger and Luckmann 1967:33-34). The validity of these types is not our problem, but before conducting our surveys we could not help but suspect that the first type, "Savior of the Union," would be mentioned most often. Without Union victory there could be no Emancipation and few would care about Lincoln's personal background. Respondents' phrasing varied. Some said that Lincoln saved the Union by preventing its disintegration: "His sole purpose was to preserve the Union;" "He was the only man that held the 
Table 1. Major Attributions to Lincoln in Two Surveys

\begin{tabular}{|c|c|c|c|c|c|c|c|c|}
\hline & \multicolumn{4}{|c|}{ Maryland Survey } & \multicolumn{4}{|c|}{ Knowledge Survey } \\
\hline & \multicolumn{2}{|c|}{ 1st Mention } & \multicolumn{2}{|c|}{ Any Mention $^{\mathrm{a}}$} & \multicolumn{2}{|c|}{ 1st Mention } & \multicolumn{2}{|c|}{ Any Mention ${ }^{\mathrm{b}}$} \\
\hline & $\mathrm{N}$ & $\%$ & $\mathrm{~N}$ & $\%$ & $\mathrm{~N}$ & $\%$ & $\mathrm{~N}$ & $\%$ \\
\hline \multicolumn{9}{|l|}{ Peterson Categories } \\
\hline 1a. Great Emancipator & 259 & 31.8 & 375 & 46.1 & 384 & 43.9 & 578 & 66.3 \\
\hline 1b. Equal Rights & 51 & 6.3 & 93 & 11.4 & 33 & 3.7 & 75 & 8.6 \\
\hline 2. Savior of the Union & 26 & 3.2 & 54 & 6.6 & 72 & 8.3 & 124 & 14.2 \\
\hline 3. Folk Themes & 16 & 1.9 & 39 & 4.8 & 22 & 2.5 & 36 & 4.1 \\
\hline \multicolumn{9}{|l|}{ Additional Categories } \\
\hline 4. Moral Traits & 91 & 11.1 & 156 & 19.2 & 39 & 4.5 & 89 & 10.2 \\
\hline 5. Leadership & 48 & 5.9 & 79 & 9.7 & 47 & 5.4 & 89 & 10.2 \\
\hline 6. Negative Beliefs & 17 & 2.1 & 29 & 3.5 & 25 & 2.9 & 37 & 4.2 \\
\hline 7. Other Positive Beliefs & 307 & 37.7 & - & - & 251 & 28.8 & - & - \\
\hline $\mathrm{N}$ & 814 & 100 & & & 873 & 100 & & \\
\hline
\end{tabular}

Note: The "Don't Know" category contained 132 responses in the Knowledge Survey and 65 cases in the Maryland survey.

a The base $\mathrm{N}$ for each percentage in the Maryland survey is 814; in addition, 122 respondents who could not name any president as great were not asked an open question about Lincoln.

$\mathrm{b}$ The base $\mathrm{N}$ for each percentage in the Knowledge survey is 873 .

country together." Others believe that Lincoln restored a Union that had already disintegrated: "He united a broken country;" "He brought the divided nation back together again." These are aspects of what we call "saving the Union." Yet, only 6.6 percent and 14.2 percent of our Maryland and Knowledge samples mentioned Lincoln as Savior of the Union.

The single most frequent explanation of Lincoln's greatness-46.1 percent in the Maryland survey and 66.3 percent in the Knowledge survey —was "Great Emancipator." The most common statement is the simplest: "He freed the slaves," but there are variants, from "Slavery was wrong; he got rid of it" and "He fought for the slaves" to "He stuck out his neck to free the slaves."

Coding "Emancipator" responses was straightforward, but many respondents gave answers that went well beyond Emancipation, and these seemed to call for a separate code, which we labeled "Equal Rights.” These respondents -11.4 percent and 8.6 percent in the Maryland and Knowledge surveys respectively-described Lincoln as a prophet of the contemporary ideal of racial equality, although evidence that Lincoln embraced such an ideal is weak, and there is considerable evidence to the contrary (Sinkler 1971; Fredrickson 1975). Typical responses in this category include "He was somewhat the father of equal rights"; "He tried to ban racism." In some cases this meant the achievement of a universalistic value: "He fought for civil rights, human rights;" "He realized it wasn't the color of the skin that mattered." In other cases, it meant a particularistic value: "He gave equal rights to minorities, specifically the African Americans"; "He addressed black civil rights." Furthermore, if we consider both "Emancipation" and "Equal Rights" responses together, fully 57.5 percent of the Maryland survey respondents and 74.9 percent of the Knowledge Network respondents gave one or both as a reason for Lincoln's greatness.

That "Emancipation," including or excluding the "Equal Rights" response, ranks so highly in both the Maryland and Knowledge Network surveys suggests that the wording of the question (emphasizing greatness in the former and how Lincoln acted in the latter) played a minor role in producing the result. Also, questionwording cannot explain the great differences between "Union" and "Emancipation" responses within each survey.

We found and coded one other Lincoln attribute commonly linked to epic achievement: presidential "leadership." In a few cases, this attribute referred to the restoring of the Union, but its stress was on Lincoln's leadership skills. "He led the country through difficult times," remarked one of our respondents. "He understood the big picture," said another. "He had to 
deal with the worst war the world has ever had." His "vision and knowledge" won the war. Almost 10 percent of the respondents in both the Maryland and Knowledge surveys attributed these qualities to Lincoln. "Leadership" is positively associated with "Savior of the Union" in both the Maryland and Knowledge surveys ( $r$ $=.12$ and .10 respectively, each with $p<.001$ ), but negatively with the "Great Emancipator" in the Maryland survey (-.13) and essentially zero in the Knowledge survey. If the "Leadership" and "Savior of the Union" categories are combined, then the totals for the Maryland and Knowledge samples would be 16.3 percent and 24.4 percent, but the percentage in both samples mentioning the "Great Emancipator" would still be more than twice as great.

\section{FOLK THEMES}

Lincoln's earthiness has led some Americans to see his presidential greatness in terms of traits he shared with the common people. Their responses reflect the biography and commemorative symbolism of (1) "Man of the People": "He was a common person"; "He understood the people and he was not a rich man. He was poor"; "He was solid down to earth"; (2) "First American": "He grew up in a log cabin"; "He would write with charcoal on the floor"; (3) "Self-made Man": "He was self-taught"; "He came from the log cabin to the presidency."

Few people answered our survey questions about Lincoln in these terms. If we combine the three sets of answers into a single category called "Folk Themes,"only 4.8 percent of the Maryland respondents and 4.1 percent of the Knowledge respondents, as Table 1 shows, fall into it. Perhaps many respondents do think of Lincoln in these terms but do not see them as reasons for "greatness," even when encouraged to give multiple responses. If this were so, however, we would obtain a higher percentage of folk respondents in the Knowledge Survey, which asks the respondent to indicate what Lincoln had done, than in the Maryland survey, which asks why Lincoln was great. This was not the case. Edwin Markham's early-twentiethcentury observation that " $[\mathrm{t}]$ he color of the ground was in him, the red earth; The smack and tang of elemental things" ([1911] 1970:14) may well have been more meaningful to earlier generations than to ours. ${ }^{8}$

\section{MORAL CHARACTER}

Another aspect of Lincoln's reputation is based on integrity, kindness, gentleness, forgiveness, and courage (which may be no less relevant to urban than to frontier life). Five types of moral attribution appeared among our responses: (1) honesty, (2) compassion, (3) bravery, (4) religiosity, and (5) other moral qualities, including fairness, virtuousness, and strong convictions. These five attributions are infrequent when taken individually, but at least one of the five is mentioned by 19.2 percent of the Maryland respondents and 10.2 percent of the Knowledge respondents, making them as a group second only to "Emancipation" as a source of Lincoln's historical identity. They are not, however, considered a major theme by Peterson.

The last category in Table 1, "Other Positive Beliefs," includes a wide range of responses, the most common of which are ambiguous phrases including "Civil War," "one of our great presidents," "decent man," "great man," "did important things." Other responses concerned physical appearance, assassination/martyrdom, visual images (statues, painting, penny), monuments, school lessons, Gettysburg Address, and a few that were wrong but positive, for example, "Father of our country."

In contrast to the volume of positive beliefs about Lincoln, 3.5 percent of the Maryland respondents (entirely from those who had not named Lincoln "great") and 4.2 percent of the Knowledge Network respondents expressed negative beliefs about his dishonesty, supposed extra-marital sex, indifference to slavery, and

\footnotetext{
${ }^{8}$ On this and all following pages, the meaning of "generation" follows Mannheim's conception: "The fact of belonging to the same generation or age group have this in common, that both endow the individuals sharing in them with a common location in the social and historical process, and thereby limit them to a specific range of potential experience, predisposing them for a certain characteristic mode of thought and experience" ([1928] 1952:291).

9 Since we did not intend to discuss the "Other Positive Responses," we collapsed them into a single category. Analysis of this category would be meaningless because it contains disparate items.
} 
the meaninglessness of his Emancipation Proclamation.

Within every subgroup of age, education, region, gender, and race, "Great Emancipator" is named most often; "Moral Traits" are next most often named; "Folk Themes," the least so. (For analysis of subgroup differences in perception of Lincoln, see Appendix B on ASR online supplement). This finding, however, is unique to our time. Understanding the process that now makes the Emancipator image the most popular requires an across-time comparison.

\section{Historical PERIOD}

The Maryland and Knowledge Network data reflect the experience of Americans at one point in time, but historical beliefs change as time passes. Without data from an earlier period we cannot be certain whether the "Great Emancipator" is more prominent now than before. Since the Maryland and Knowledge Network surveys were administered at a time when minority rights were foremost in the public's mind, we want to know whether similar results obtain from surveys administered at a time when racial justice and minority rights were not major public issues.

Respondents from Gallup's wartime survey of January, 1945, a period of intense fighting in Europe and Asia, and from the National Employee Survey carried out shortly after September 11, 2001, provide us with a means of comparison. ${ }^{10}$ By eliminating non-employees from the Gallup survey, we produced two closely matching samples with no retirees, full-time housewives, or unemployed. When we compared findings in the matched sample to the full Gallup sample, however, the differences were insignificant and, in fact, almost identical. (See Appendix E on ASR online supplement for comparison of matched and full Gallup samples.) To the 2001 National Employee Survey we attached the two questions posed by Gallup's 1945 interviewers: "Who do you think was the greater man,

10 The National Employee Survey, conducted by Paul Roman, University of Georgia, is the third in a series of surveys dealing with workplace experiences and problems.
George Washington or Abraham Lincoln?" and "Why?" We also coded the Employee Survey reasons for ranking Lincoln above Washington into categories comparable to those reported by Gallup. (For verbatim description of the Gallup and Employee Survey response codes, see Appendix C on ASR online supplement.)

When the Gallup Poll asked the 1945 sample "Who was the greater president: George Washington or Abraham Lincoln?" 42 percent of the respondents named Lincoln. In 2001, 51 percent of the Employee Survey respondents named Lincoln - an increase of 9 percent. In 1945, 22.7 percent named Washington; in 2001, 21.3 percent. The percentage naming both equal in 1945 and 2001 were 27.2 and $20.8 \%$ (Chi-square, $d f=2, p<.01$ ). Since Lincoln and Washington have long symbolized the ideals of equality and liberty respectively (Karsten 1978; Cunliffe 1988; Zelinsky 1988), the increase in Lincoln's prestige relative to Washington's suggests an expansion of egalitarianism relative to libertarianism in American society. ${ }^{11}$

Between 1945 and 2001, Americans gave different reasons for their rankings, and these enable us to compare by period the relevance of Merrill Peterson's five Lincolns. The 1945 survey allowed for one response per individual, which we compared to 2001 "First Mentions" only. (For a comparable table showing Employee Survey "Any mentions," see Appendix D on ASR online supplement). Like their 1999 Maryland and 2001 Knowledge Network counterparts, the 2001 National Employee Survey's respondents named Lincoln the "Great Emancipator" (31.0\%) more often than "Savior of the Union" (4.8\%), and anoth-

11 The greater percentage of Lincoln mentions in 2001 compared to 1945 appears in all demographic categories, but mostly in the South and West and among whites generally. In the South, the percentage choosing Lincoln over Washington increased from $30 \%$ in 1945 to $47 \%$ in 2001 . In the West, the comparable figures are $47 \%$ and $62 \%$. Thus, the South is just below the national average of $51 \%$; the West, far above that average. In both 1945 and 2001, $51 \%$ of African Americans chose Lincoln over Washington. In 1945, 41\% of whites chose Lincoln; in $2001,50 \%$. 
Table 2. Reasons for Designating Abraham Lincoln Greater than George Washington: 1945 Gallup Poll Survey and 2001 NES

\begin{tabular}{lcr}
\hline \hline & $\begin{array}{c}\text { 1945 Gallup Poll (\%) } \\
(\mathrm{N}=906)\end{array}$ & $\begin{array}{c}2001 \mathrm{NES}(\%) \\
(\mathrm{N}=1,378)\end{array}$ \\
\hline 1. Emancipator, Savior of the Union ${ }^{\mathrm{a}}$ & 26.1 & 41.7 \\
2. Common Man, People's President & 26.3 & 4.4 \\
3. Self-made Man & 23.3 & 3.1 \\
4. Honesty & 1.7 & 2.0 \\
5. Greater Statesman & 2.1 & 11.8 \\
6. Greater Problems & 7.4 & 8.4 \\
7. Greater Communicator & 2.1 & 1.2 \\
8. Washington's Shortcomings & 1.0 & 1.4 \\
9. Miscellaneous & 10.0 & 26.0 \\
Total & 100.0 & 100.0 \\
\hline
\end{tabular}

Notes: The 1945 percentages are based on an $\mathrm{N}$ of 906, which excludes 23 nonresponses. The 2001 percentages are based on an $\mathrm{N}$ of 1,378, with 104 nonresponses and 45 uninterpretable responses excluded. The numbers in each column add to $100 \%$ because the Gallup survey allows for one response; the NES results are calculated on first response only. See Appendix C for the codes included under the NES "Miscellaneous" category. The Gallup "Miscellaneous" codes are unknown. NES = National Employee Survey.

${ }^{a}$ In the 2001 NES, this category consisted of three separately coded components: Saving the Union $=4.8 \%$; Emancipation $=31.0 \%$; Equal Rights $=5.9 \%$.

er 5.9\% mentioned "Equal Rights" (See Table 2 , note a). Thus, based on a third sample of contemporary Americans and still different questions about Lincoln, the Employee Survey findings provide further evidence of the cultural power of the "Great Emancipator."

The 1945 Gallup survey coded "Union" and "Emancipation" responses into a single category (possibly because the practical connection of Union and emancipation was clearer in the coders' minds than in ours). To make the Employee Survey comparable to Gallup's we had to combine "Great Emancipator" and "Savior of the Union" responses into a single category also. Into this combined category fell 26.1 percent of the earlier Gallup respondents and 41.7 percent of the Employee Survey respondents (Table 2). Even if the 26.1 percent falling into Gallup's category contained only "Emancipator" mentions, there would still be fewer such mentions in 1945 than in 2001 ( $p<$ $.01)$, when 31 percent named Lincoln the Great Emancipator. When we include the "Racial Equality" responses in the 2001 "Emancipation" category (the only category in which they could possibly fit in 1945), the "Great Emancipator" figure becomes 36.9 percent (Table 2, note a). If the ratio of "Emancipation" to "Union" responses was the same in 1945 as in 2001, "Emancipation" would have contributed 22 percent to the 1945 total of 26.1. If the ratio of
"Emancipation" to "Union" responses was lower in 1945, which, as the next section will show, is most probable, the direction of the $1945 / 2001$ difference would be even more pronounced.

From 1945 to the present, the substance of Lincoln's reputation changed in other, equally important, ways. In the 1999 Maryland and 2001 Knowledge Network samples, few saw Lincoln as a folk hero. The 2001 Employee Survey results displayed in Table 2 also show few "Folk Theme" mentions: only 3.1 percent identified Lincoln as a "Self-Made Man" and 4.4 percent, as a "Common Man and People's President," comparable to Peterson's "Man of the People." In 1945, however, 23.3 percent saw Lincoln as a "Self-Made Man" and 26.3 percent identified him as a "Common Man and People's President." 12 These differences, which appear in all categories of age, education, region, gender,

\footnotetext{
${ }^{12}$ Appendix C (on ASR online supplement) shows close correspondence between the coding instructions for the 1945 and 2001 categories; but there is one exception. We cannot be certain that the content of our NES 2001 "Leadership" category corresponds to Gallup's undefined 1945 "Greater Statesman" category. The first, second, third, and fifth row differences reported in Table 2, assessed by difference of proportions tests, are significant beyond the .01 level.
} 
and race, correspond to differences in experience. Almost all Gallup's 1945 respondents were born before 1925, when more than half of America's population resided in non-urban places and more than 25 percent of the labor force was agricultural (U.S. Bureau of the Census 1975:11; 1990:17). One-third of this population was born and reared in the early Jim Crow era (the end of the nineteenth century); most of the rest were their children. Gallup's white 45 year-olds, born in 1900, can be thought of as having participated in the segregated 1909 Lincoln Centennial celebrations, learned about Lincoln from Ida Tarbell's populist biographies, admired Lincoln's freeing the slaves without ever associating Emancipation with racial equality and, as 22 year-olds, cheered when President Harding dedicated the Lincoln Memorial expressly to North-South-not white-blackreconciliation.

Reared in a society still suffused with the values of the farm and small town, living through a severe, decade-long depression and a World War, people in 1945 saw in Lincoln a multidimensional man - a Savior of the Union and, yes, paternalistic Emancipator, but even more a compassionate Man of the People and Self-Made Man. The 1945 Gallup Poll thus captured the Lincoln of 1930s film, poetry, statuary, and biography (Schwartz 2005) - all of which portrayed a man of gentleness and toughness, a common man performing epic deeds.

Present perceptions of Lincoln as Emancipator and Champion of Racial Justice differ from those of 1945, but when did the transformation begin? Do data on individual beliefs answer this question differently from data drawn from historical and commemorative archives? How did new understandings about America's minorities affect new ways of seeing Lincoln?

\section{CIVIL WaR, CIVIL RIGHTS, AND tHE FIVE LINCOLNS}

Three surveys-Maryland, Knowledge Network, and National Employee-present a man whose greatest achievement was not so much to make the nation stronger as to redeem its sins and protect the weakest of its citizens. In America, white racial attitudes began turning positive after World War II (Frederickson 2002; Schuman, Steeh, Bobo, and Krysan 1997), and this shift aided public acceptance of changes initiated by the courts, the government, and even such private organizations as baseball teams. Late twentieth-century minority rights revolutions (Skrentny 2002) and race pride movements (Rhea 1997) accelerated these trends. Don Fehrenbacher (1968) was among the first to observe the civil rights movement drawing scholarly attention to slavery, but he had no idea how intense this new focus would become. From the New York Times Index we recorded the number of slavery entries (relating to America) for the first year of each decade from 1910 to1980. Never more than two articles about slavery appear. The production of slavery articles rose abruptly, however, from four in 1990 and 1992, to 28 in 1998, 61 in 2000, and 80 in 2001. Similar trends appear in both Reader's Guide to Periodical Literature and American Book Publishing Record. ${ }^{13}$

Rising interest in slavery corresponds to historians' reinterpretation of the Civil War. During the 1920s and 1930s, leading historians believed the Civil War resulted from extremist agitation in the North and South, that Emancipation failed to affect the lives of the black masses, that the war's horrendous costs could never be justified. ${ }^{14}$ Contemporary historians are more inclined to consider the war inevitable and morally just, to sympathize with abolitionists and Radical Republicans, to judge Emancipation and Reconstruction more important than NorthSouth reconciliation, and to include extrem-

${ }^{13}$ In the Readers' Guide to Periodical Literature, the average annual number of articles on American slavery, sampled at ten-year intervals, was 7.0 between 1900 and 1990. After 1990, the average increased to 24.8. The trend's spike of 65 articles occurs in 1998. The American Book Publishing Record's trend, sampled at two-year intervals, is less distinctive but in the same direction: in the 1980s an annual mean of 32.2 books was published; from 1990 to 1997 , the mean was 35.2. From 1998 to 2001 the annual average rose to 51.3 books. Slavery publications increase during the late 1990s and early 2000s.

${ }^{14}$ Reflecting their generation's disillusionment with World War I and reacting against the "national" tradition of Civil War history, James G. Randall, Wesley Craven, Reinhard Luthin, Benjamin Thomas, and T. Harry Edwards, among other historians, formed the Revisionist school of Civil War history. 
ists- John Brown, William Lloyd Garrison, and Thaddeus Stevens - among the war's heroes. The "Savior of the Union" and "Man of the People" images resonate with David Blight's (2001) "reconciliationist memory" of the Civil War, which assumes that decent men from the North and South fought gallantly for their respective beliefs and should respect one another's heritage. On the other hand, the new Lincoln, the "Great Emancipator," resonates with "emancipationist memory," which defines the war's essence as a struggle for racial justice. We are now in the midst of the first great surge of emancipationist memory.

Emancipationist memory, although reflected in the content of history textbooks produced during the past 25 years, is not uniquely determined by historians. Textbooks, in fact, are benchmarks indicating how far popular memory, marked by survey data, can outrun changes in elite memory, marked by academic production. Both authors and readers are members of the same social world, but they react to it in different ways. Our concern will be to explore this relationship.

Before the mid-1960s, most textbook writers define the saving of the Union as Lincoln's major goal; since then, an unprecedented number of scholars believe that Northern Republicans supported the war to restore the Union but gradually saw Emancipation as its major purpose and justification. One of the present authors and a second reader reviewed carefully 40 high school textbooks (Appendix F on $A S R$ online supplement): three to seven texts for each decade between 1920 and 1999; two, for the year 2000. ${ }^{15}$ All books published during or prior to the 1970 s were sampled from Frances Fitzgerald's bibliography of widely used history texts (1979:227-34). Those published after 1980 were selected from a school of education library. The textbooks were available to different generations of students and indicate the

\footnotetext{
${ }^{15}$ For each generation of textbooks considered, i.e., texts published between 1920 and 1944; 1945 and 1964; and 1964 to present, the author and second reader agreed on the relative emphasis of "Union" and "Emancipation." "Emancipation" bore a utilitarian, subordinated, relation to "Union" until 1965; after 1965, "Emancipation" assumed a significance equal to or greater than "Union."
}

changing relevance of "Union," "Emancipation," and the "Folk Theme." As such, they provide one approximation of the turning point in Lincoln's reputation - the last third of the twentieth century during which the relevance of the "Great Emancipator" began to supercede that of the "Savior of the Union," "Man of the People," "First American," and "Self-Made Man."

\section{PREWAR TEXTBOOKS: 1920-I944}

Between 1915 and 1944, when most members of Gallup's sample were educated, writers described slavery as a moral wrong but defined Emancipation as an instrument of Union victory, never an end in itself. The rationale for Emancipation was to weaken the South's labor force, augment the Union's manpower, and prevent European countries from recognizing the Confederacy. The narrative, centering on the state and its salvation, is textured with pictures of military and political scenes, monuments, memorials, statues, and portraits of leading generals and statesmen. Representations of slavery are sparse. Slavery is represented as a philosophical rather than humanitarian evil, not so much a source of concrete suffering as a violation of the principles of free labor, sanctity of private property, and individual liberty.

Almost all pre-1945 textbooks cover Abraham Lincoln's life extensively, noting his being born in poverty and reared on the frontier, and his achieving the presidency by hard work. They describe the log cabin where he was born and his simple manner, and they show pictures of him chopping wood and reading books. Civil War-era women, in the little space devoted to them, appear as housewives and supportive mothers. These themes endure through the 1970s, but less conspicuously after World War II than before.

\section{Postwar TeXtBooks: 1945 TO PRESENT}

Textbook contents between 1945 and 2001 move in the same direction as changes evidenced in the Gallup and National Employee surveys. Against the background of World War II, the Cold War, Soviet condemnation of American racial segregation, and, above all, the growing fury of Southern black protest (1945-64), textbook writers devote more space to Emancipation but continue to see the Union's preservation as Lincoln's goal. In texts published after 1965, 
however, a widespread commitment to social reform finds expression in reformist portrayals of Lincoln and the Civil War. To sustain this new understanding, the salience of the categories of "Great Emancipator" and "Savior of the Union" had to shift. That Emancipation widened the war's purpose, an assertion characteristic of the earliest textbooks, is reiterated, but some prominent writers in the late 1960s and 1970s (including Platt and Drummond 1966; Wilder, Ludlum, and McCune 1966; Todd and Curti 1972) began to assert that moderate Americans - not just abolitionists - perceived Emancipation as the primary war goal rather than an instrument for winning the war. In the 1980 s, too, historians like Melvin Schwartz and John O'Connor explain, "People in the North had felt they were fighting to keep the Union together," but emphasize that "[n]ow they also felt they were fighting to free the slaves" (1986:320). Winthrop Jordan, Miriam Greenblatt, and John Bowes went further: "The Emancipation Proclamation gave the Northerners the weight of a moral crusade and began to replace Union as the war goal" (1985:348, see also p. 345; Sellers et al 1975). In William McFeely's (1983) words, the "uneasy relationship between black and white people, rich and poor people, is what the Civil War was about."

During the 1990 s, as slavery representations multiplied in the mass media and book publications, the emancipation theme became even more prominent. The Northern population, according to Henry Bragdon, Samuel McCuthen, and Donald Ritchie (1992), could never justify the war's carnage by mere restoration of the Union; the Emancipation Proclamation "aroused a renewed spirit in the North" and strengthened the will to win the war ( Downey and Metcalf 1997:375, 461-62). Lincoln at Gettysburg "announced to the world that the abolition of slavery had become a major purpose of the Civil War." The death of so many men would have meaning only if the country remained "dedicated ... to the unfinished work which they who fought here have thus far so nobly advanced." This unfinished work was not the saving of the Union but "the movement to free the slaves and an enduring commitment to racial justice" (Boyer, Todd, and Curtis 1995:379-80). Since slavery was the war's only moral issue, Emancipation was the cement that held the North together (Buggey et al. 1987:391).

Post-1965 texts not only reinterpret the relationship between Emancipation and Union; they discuss it in a new context that redefines the war's meaning. Centering on liberation, the narrative is filled with representations of the African American experience. "Until the midsixties," Frances Fitzgerald observes, "black Americans had hardly entered the textbooks at all" (1979:83). After the mid-sixties, textbook authors make up in intensity what their forebears ignored. They name slavery an evil, define its psychological effects, display pictures of human neck yokes, slaves being auctioned and laboring in the field, runaways being captured, black citizens brutalized during Reconstruction. They discuss black contributions to the war effort and show pictures of black soldiers individually and in action against the enemy. In addition, they discuss the wartime fight in the North against discrimination toward free blacks in work, schools, and local places. They relate information about the Underground Railroad, depict John Brown's martyrdom, draw liberally on slave narratives, and consider the fate of blacks after Emancipation. Lincoln's racial attitudes, his concern for the well-being of emancipated slaves, and the accomplishments of African American leaders are common topics. Teacher guides recommend connecting the wartime situation of blacks to present civil rights issues. During the last third of the twentieth century, then, textbooks reconfigure the Civil War's purpose by devoting more space to the experience of slavery.

Multiculturalism and interest in minorities enhances emancipationist memory. Textbooks, for example, devote unprecedented attention to the role of women. They identify white women performing espionage and combat roles, working in factories, managing homes, farms, and plantations in their husbands' absence, and they provide information on black and white women administering medical care, nursing, teaching, mobilizing drives for reading materials, food, and other support. Irish, German, and Native American contributions are also discussed in the Civil War chapters, although more briefly than those of African Americans. Emphasizing "history from below" is logically unrelated to the war's purpose, but by recognizing minority experience, writers make Emancipation more 
plausible as a primary war goal and transform the Civil War from a tragic to a necessary struggle. (For fuller discussion of late twentieth-century changes in textbook content, see Lerner et al. 1995; Sewall 2001.)

Table 3 summarizes the main axes of difference between early and later American history textbooks. All textbooks describe Emancipation's purpose, institutionalization, and function. Reading across the table's seven rows, these topics involve the Union's relevance becoming subordinated to that of slavery. The priority of Emancipation over Union is conveyed by multicultural symbols replacing symbols of the strong state, of freed slaves replacing images of young Lincoln as exemplifications of equality, of a social equality champion replacing a folk hero. Thus, the way we think about Lincoln, Table 3 shows, is an aspect of the way we perceive the Civil War.

\section{HISTORY, COMMEMORATION, AND BELIEF}

Differences between history texts written before and after World War II are considerable, but their variation is a matter of emphasis. If understanding individual beliefs about Lincoln depended solely on textbook content, we would, in fact, vastly underestimate the increased sig- nificance of Emancipation between 1945 and 2001. No contemporary historian, not even the most radical, asserts that Lincoln would have initiated a war to free the slaves if eleven Southern states had not seceded. In our Maryland and Knowledge Network data, however, 46 and 66 percent respectively mention the emancipation, compared to 7 and 14 percent mentioning the preservation of Union as Lincoln's greatest feat. Likewise, Lincoln the "Folk Hero" is mentioned by approximately one-quarter of late-twentieth-century textbooks but by only 5 and 4 percent of the Maryland and Knowledge Network survey respondents respectively. In the Gallup-National Employee Survey comparison, moreover, the "Common Man and People's President" drops from 26.3 to 4.4 percent; the "Self-made Man," from 23.3 to 3.1 percent respectively (Table 2).

When commemorative and survey trends are compared, the problem of ignoring individual belief becomes even more apparent. Although textbooks are written annually, the production of monumental symbolism peaks in definite decades, then ceases. Most prominent Lincoln icons, monuments, shrines, and place names were dedicated before 1950; since then, their number has remained steady while beliefs about Lincoln have changed dramatically. Since changing beliefs are occurring against a rela-

Table 3. Characteristic Features of Civil War Chapters in American History Texts Published before and after 1965

\begin{tabular}{|c|c|c|}
\hline Topic & Before 1965 & After 1965 \\
\hline $\begin{array}{l}\text { 1. Purpose of War after } \\
\text { Emancipation Proclamation }\end{array}$ & Save union; free slaves & Save union; free slaves \\
\hline $\begin{array}{l}\text { 2. Function of Emancipation } \\
\text { Proclamation }\end{array}$ & $\begin{array}{l}\text { Instrumental (weakens } \\
\text { Confederacy) }\end{array}$ & Moral (justifies war) \\
\hline 3. Key Problem & Unity of states & Institution of slavery \\
\hline 4. Priority & Union $>$ Emancipation & Emancipation > Union \\
\hline $\begin{array}{l}\text { 5. Illustrations and Examples } \\
\text { Accompanying Text }\end{array}$ & $\begin{array}{l}\text { Symbols of strong state and domi- } \\
\text { nant political culture: history } \\
\text { paintings, statues of military and } \\
\text { political men, monuments, shrines }\end{array}$ & $\begin{array}{l}\text { Multicultural symbols: } \\
\text { Representations of the slave } \\
\text { experience, pictures and stories of } \\
\text { African American soldiers, politi- } \\
\text { cal figures, women, Native } \\
\text { Americans, immigrants }\end{array}$ \\
\hline 6. Representations of Equality & $\begin{array}{l}\text { Pictures of young Lincoln, log } \\
\text { cabin; accounts of Lincoln's } \\
\text { social background and ambition; } \\
\text { vertical mobility as symbol of } \\
\text { equality }\end{array}$ & $\begin{array}{l}\text { Freed slaves and assimilated but } \\
\text { culturally distinct minorities as } \\
\text { symbols of equality }\end{array}$ \\
\hline 7. Primary Image of Lincoln & $\begin{array}{l}\text { Epic hero (Savior of Union) and } \\
\text { folk hero }\end{array}$ & $\begin{array}{l}\text { Epic hero (Great Emancipator) and } \\
\text { champion of social equality }\end{array}$ \\
\hline
\end{tabular}


tively fixed commemorative backdrop, Lincoln monuments are more likely than texts to be screens on which new beliefs are projected.

\section{HISTORY OF MEMORY AS A SUPPLEMENT TO THE NEW STRUCTURAL MEMORY}

Historical figures resonate with contemporary experience when their personalities or achievements engage the presuppositions of the people encountering them. Since these presuppositions are patterned by group and generational experience (Griswold 1987b; Schuman and Scott 1989), there is some analogy between the present analysis of collective memory, based on what beliefs individuals take from history books and commemorative symbolism, and reader reaction studies, which ask individuals what they get from romance novels and other popular books (Radway 1984, 1997) or how reviewers in different countries react to identical novels (Griswold 1987b). ${ }^{16}$ Like these readers, individuals holding beliefs about Lincoln are not passive end-links on some chain of causation; they reinforce or modify the texts and symbols they consume. The succession of historical perceptions is therefore mediated not only by producers, like authors and artists, but through the interaction of producers and recipients. When analysis of collective memory is grounded in reception, the producer's dependence on consumer reaction comes more fully into view, as does the latter's role in generating collective memory's vicissitudes. "Culture creation" and "culture-reception" are inseparable (Griswold 1987a; Wertsch 2002), but we can explore this connection only if we know what individuals, as cultural recipients, actually believe.

Surveys assess individual beliefs as outcomes, but they cannot capture the process leading to them. We can imagine teachers in 1945 telling their students that Lincoln at Gettysburg

\footnotetext{
${ }^{16}$ Although we place aggregated survey responses in the context of aggregated texts and symbols, we cannot know which particular texts and symbols particular individuals are apprehending. This shortcoming distinguishes our method from that of reader reaction studies. We know only that texts and symbols (cultural objects) contextualize individual beliefs (reception), and it is from this relation that we draw inferences about causation.
}

praised the soldiers who died to save democracy; parents at Lincoln's Springfield home telling their children, "Here lived the poor, common man who made himself president by hard work"; tourists visiting the Lincoln Memorial gazing at its powerful references to Union. We can test hypotheses about contemporaries' reaction to these objects, however, by combining qualitative and survey methods. As Lincoln appears against a changing "horizon of expectations" (Jauss 1982:3-45) based more on equality than unity, focus groups, depth interviews, direct observations, and on-site interviews can reveal a mnemonic resocialization process (Zerubavel 2003) beyond the survey's reach: teachers telling their students that Lincoln at Gettysburg praised the soldiers who died to bring about racial justice; parents waiting to enter the Lincoln home telling their children, "Here lived the man who freed the slaves"; tourists visiting the Lincoln Memorial admiring the statue of the Great Emancipator, ignoring its declaration of gratitude to the Union's Savior.

Aggregation of individual beliefs affects the environment from which they emerged. As this environment's horizon of expectation becomes emancipationist, it inspires and welcomes modification of old structures, like the Lincoln Memorial plaque that commemorates Martin Luther King Jr.'s "I Have a Dream" speech; promotes the canonization of old structures, including the placement of the long-forgotten Soldiers' Home, where Lincoln drafted the Emancipation Proclamation, into the National Historical Registry; and influences the policy of new organizations, including the Abraham Lincoln Bicentennial Commission, which has adopted the premise that the Emancipation Proclamation redefined the Civil War, "changing it from a war for Union to a war for human freedom," and has explicitly made Lincoln's association with racial equality its major focus (U.S. Abraham Lincoln Bicentennial Commission 2004:7, 48).

The seriousness with which any writer or artist assumes his audience's standpoint, reflected in beliefs about Lincoln arrayed in tables 1 and 2, is a measure of the power of individual beliefs to affect the media that represent them, but we would never know about the climate of belief to which historians and artists adapt if we failed to assess it. The history of memory (trends in individual belief) supplements the structure 
of memory (textual and symbolic patterns) because the former help explain the latter's persistence and change. Therefore, belief is both a source and product of Lincoln representation.

Modernizing images of Lincoln may bring them closer to or further from reality; but since every generation believes the image it entertains of him to be the truest, the last thing its members consider is how future generations will regard him. If the Union's permanence can be taken for granted today, future generations taking racial harmony for granted might find Lincoln's racial views irrelevant to their concerns. When the social movements that have formed these concerns reach completeness, as they eventually must, the ground supporting them will lose its resonance with life.

\section{CONCLUSION}

The New Structural Memory contributes rich insights into the workings of history and commemoration, but it ignores the question of how individuals think about the past. America's five Abraham Lincolns - Savior of the Union, Great Emancipator, Man of the People, First American, and Self-Made Man-exemplify this point. There is no way to determine from a cumulative body of texts and symbols which of the five Lincolns is most relevant today. Only when we ask individuals about Lincoln's greatness or what comes to mind when they think of him or why he was a greater president than another do we realize the importance they place on Emancipation and, beyond that, on his imagined commitment to civil rights as presently understood. If we had not compared our surveys to Gallup's earlier evidence, we would not know that the one-sided imagination of Lincoln as emancipator was alien to the American mind of the mid-1940s, and that emancipator imagery typifies contemporary beliefs even more than do contemporary texts and symbols.

George Homans (1964) brought individuals back into sociology (dominated in his time by functional theory) because he believed psychological dynamics drive social structures and cultural patterns. We bring individuals into collective memory (dominated now by structural theory) because they alone, as creators and recipients, ascribe meaning to historical and commemorative objects. In our introduction, we posed four interrelated questions about meaning's ascription. The first question asked "How far, if at all, do individual beliefs deviate from historical and commemorative statements?" In Lincoln's case, individuals plainly exaggerate such statements. Textbooks affirm Union's importance but place far more emphasis on Emancipation during the last third of the twentieth century. Among the individuals we surveyed, however, this emphasis is magnified: the "Great Emancipator" has for the most part swallowed up the "Savior of the Union" and rendered the "Folk Hero" marginal.

The second question was "Do historical and commemorative statements change at the same rate and in the same direction as individual beliefs?" Comparison of the 1945, 1999, and two 2001 surveys show that the importance of "Saving the Union" and "Folk Themes," relative to "Emancipation," fell faster within the public than among history book writers. The "Common Man and People's President" was mentioned in surveys more than six times as often in 1945 as in 2001; the "Self-made Man," more than four times as often; the "Emancipator," as well as we can estimate, about half as often.

Any answer to the third question, "How and to what extent do beliefs, historical, and symbolic representations affect one another?" must be tentative. Comparing 1945 and 2001 shows that a population believing in Lincoln as "Great Emancipator" not only produces writers and artists who define him as such but also provides these writers and artists with an appreciative audience. Lincoln's memory, then, is embodied not in a succession of books and symbols consumed passively but in a succession of books and symbols actively embraced, rejected, and shaped, by their consumers.

"Which aspects of late-twentieth-century American society do [Lincoln] representations symbolize?" was our fourth question. The primary social fact of the late twentieth-century, the revolution in race relations, frames our findings. Despite continuing debate about "states' rights," virtually all Americans take the permanence of Union for granted, and Lincoln's rescuing it is one of the last things about him that comes to mind. The Civil War makes sense today as a struggle for racial equality, and the "Great Emancipator" explicates the meaning of this new interpretation, puts definite constructions 
on the events associated with it, and drives the connotation of those events into the open where people can see it and grasp it in a collective as well as personal way. Specifically, the disadvantage of contemporary African Americans seems more understandable as a product of slavery, while slavery itself seems less relevant apart from its legacy of affliction.

Recognition of history's victims is one of the mechanisms that has transformed American memory. Revisionist historians, to take one example, freely describe Columbus's crimes against native peoples, and Columbus Day now generates protest as well as celebration. Several national surveys, however, show beliefs about Columbus to be almost uniformly positive (Schuman, Schwartz, and d'Arcy 2005, forthcoming). Revisionists have been less than successful partly because the Indians whom Columbus is perceived as having oppressed are a smaller and less vivid presence than African Americans, whom Lincoln is perceived as having freed.

Through the Columbus and Lincoln cases runs a generalizable pattern. George Washington's presidential policy toward Indians was highly conciliatory, but today (notwithstanding Wiencek 2003) he is more distinguished by his status as slave holder. President Andrew Jackson's atrocity against the Cherokees is less known today than Thomas Jefferson's alleged sexual liaison with his slave; but if the target of Jackson's offenses had been African Americans his reputation would also be badly tarnished. The public's affection for Franklin Roosevelt would likewise lessen if he had approved the internment of African Americans rather than Asian Americans. Given Lincoln's reputation as a friend of oppressed minorities, his remarks about the social inferiority of African Americans and Native Americans rarely appear in textbooks and media, and they seem incongruent when they do. That his prestige would be lower had he espoused the interests of Indians rather than African Americans follows from a horizon of expectations defined by the African American civil rights movement. This new horizon shapes the reception of Columbus, Washington, Jefferson, Jackson, and Roosevelt as well as Lincoln.

The fading of the "Union's Savior" and "Folk Hero," like the rise of the "Great Emancipator," is symptomatic of a victim-and trauma-centered framework of collective memory (Eyerman 2001; Giesen 2004). In a society whose past is more of a moral burden than source of inspiration, where the "duty to remember" applies more to atrocity than to heroic achievement (Booth 1999), the "Savior of the Union," standing less firmly for "accountability," is less relevant than the "Great Emancipator." A prominent place no longer exists for the down-to-earth people's president sitting beside a cracker barrel peeling an apple and telling jokes, nor even for the compassionate president brooding over casualty figures and visiting wounded soldiers. The beneficiaries of this kind of humanitarianism have always been white men. Less relevant, even, than the kindly "Man of the People" is the "Self-made Man," the dynamo who relies on his own will and wit to rise from log cabin to White House. When linked, these last two images, rooted in the nineteenth-century world of the frontier and free market, a world in which minorities were despised, fail to inspire the best in modern leaders determined to bring all people together. The individualist ideal of hard work remains important today, but social equality is more relevant. Bill Clinton, John Edwards, and Dennis Kucinich have worked as hard to achieve their stature as Colin Powell, Condoleeza Rice, and Joseph Lieberman, but the latter's minority status gives their success greater moral resonance because it affirms the egalitarian ideal (For detail on the relative salience of individualism and egalitarianism, see Ellis and Wildavsky 1989; Thompson, Ellis, and Wildavsky 1990).

Since preoccupation with past discrimination and sympathy for the wronged are part of the present horizon of expectations, they affect what people learn when they read biographies, look upon statues, and visit shrines (Griswold 1987a: 10-16). No horizon of expectation, however, can be totally new, totally devoid of tradition's traces. Even now, many people think of Lincoln as did his contemporaries, for today's Lincoln, "our Lincoln," is largely constituted by the Lincoln of yesterday. Indeed, to assume that changing historical reputations are necessarily congruent with the changing tastes and expectations of society eventually leads to a dilemma, for the significance of historical figures inheres precisely in their transcending the mores of 
their own time. This is why new Lincoln themes have not entirely replaced traditional ones. Most of our respondents associate Lincoln with Emancipation and racial justice; but the number associating him with the preservation of the Union, identification with the common man, the frontier, and self-reliance, although small, is significant, and these themes remain available for exploitation (or rejection) by future generations.

Given the place of reception in collective memory, what is to be said about the New Structural Memory? Merrill Peterson's Abraham Lincoln in American Memory exemplifies the structural perspective because it portrays the past largely as material artifact. The Savior of the Union, Man of the People, First American, and Self-Made Man live still, and their prominence, as Peterson conceives it, is equivalent in print, canvas, and stone. At the turn of the twenty-first century, however, the image of the Great Emancipator appears most relevant to most Americans. Measuring belief apart from texts and symbols would be unnecessary if it could be inferred from them. Since this is not always the case, we have no choice but to bring individual men and women into our understanding of collective memory. Collective memory does not consist of individual beliefs alone. Bringing men and women into collective memory scholarship is an effort to widen, not narrow, its scope. Collective memory, then, refers neither to history, commemoration, nor individual belief, but to the relations among them.

Barry Schwartz, Professor Emeritus of Sociology, University of Georgia, has addressed collective memory issues through numerous topics, including American presidents. His book, Abraham Lincoln and the Forge of National Memory traces popular images of Lincoln from 1865 to 1922. His second volume, Abraham Lincoln at the Millennium, nearing completion, traces Lincoln's images from the Depression decade through the turn of the twenty-first century.

Howard Schuman is Professor and Research Scientist Emeritus, University of Michigan. In addition to long-term research on questions and answers in surveys as in life, he has drawn on survey research and content analysis to explore collective memories, including a recent article on "Elite Revisionism and Popular Beliefs: Christopher Columbus, Hero or
Villain?" in the journal Public Opinion Quarterly (2005)

\section{REFERENCES}

Basler, Roy P. 1935. The Lincoln Legend. New York: Octagon.

Bellah, Robert N. 1976. "Civil Religion in America." Pp. 168-192 in Beyond Belief: Essays on Religion in a Post-Traditional World. New York: Harper \& Row.

Berger, Peter L. and Thomas Luckmann. 1967. The Social Construction of Reality: A Treatise in the Sociology of Knowledge. Garden City, NY: Doubleday.

Blight, David. 2001. Race and Reunion: The Civil War in American Memory. Cambridge, MA: Harvard University Press.

Booth, W. James. 1999. "Communities of Memory: On Identity, Memory, and Debt." American Political Science Review 93:249-63.

Boyer, Paul, Lewis P. Todd, and Merle Curti. 1995. The American Nation. Austin, TX: Holt, Rinehart, and Winston.

Bragdon, Henry W., Samuel P. McCuthen, and Donald R. Ritchie. 1992. History of a Free Nation. Lake Forest, IL: Glencoe.

Buggey, Joanne, Gerald A. Danzer, Charles L. Mitsakos, and Fredrick Risinger. 1987. America! America! Glenview, IL: Scott, Foresman and Company.

Confino, Alon. 1997. "Collective Memory and Cultural History: Problems of Method." American Historical Review 102:1386-1403.

Cooley, Charles Horton. [1902] 1964. Human Nature and the Social Order. New York: Schocken.

Coser, Lewis A., ed. 1992. Maurice Halbwachs on Collective Memory. Chicago, IL: University of Chicago Press.

Crane, Susan A. 1997. "Writing the Individual Back into Collective Memory." American Historical Review 102:1372-85.

Cunliffe, Marcus. 1988. The Doubled Images of Lincoln and Washington. 26th Annual Robert Fortenbaugh Memorial Lecture. Gettysburg, PA: Gettysburg College.

Donald, David Herbert. [1947] 1989. "The Folklore Lincoln.” Pp. 144-66 in Lincoln Reconsidered. New York: Vintage.

Douglas, Mary. 1987. How Institutions Think. London, England: Routledge and Kegan Paul.

Downey, M.T.G. Jr. and E. D. Metcalf. 1997. United States History: In the Course of Human Events. St. Paul, MN: West Publishing.

Durkheim, Emile. [1895] 1964. The Rules of Sociological Method. New York: Free Press.

- [1911] 1974. "Individual and Collective 
Representations." Pp. 1-34 in Sociology and Philosophy by Emile Durkheim, edited by Talcott Parsons. New York: Free Press.

Eyerman, Ron. 2001. Cultural Trauma: Slavery and the Formation of African American Memory. Cambridge, England: Cambridge University Press.

Ellis, Richard and Aaron Wildavsky.1989. Dilemmas of Presidential Leadership: From Washington Through Lincoln: A Cultural Theory. New Brunswick, NJ: Transaction.

Fehrenbacher, Don .1968. The Changing Image of Lincoln in American Historiography. Oxford, England: Oxford University Press.

Fentress, James and Chris Wickham. 1992. Social Memory. Oxford, England: Blackwell.

Fine, Gary A. 1996. "Reputational Entrepreneurs and the Memory of Incompetence: Melting Supporters, Partisan Warriors, and Images of President Harding." American Journal of Sociology 101:1159-93.

Fitzgerald, Frances. 1979. America Revised: History Textbooks in the Twentieth Century. Boston, MA: Little, Brown.

Frederickson, George. 1975. "A Man but Not a Brother: Abraham Lincoln and Racial Equality." Journal of Southern History 61:39-48.

- 2002. Racism: A Short History. Princeton, NJ: Princeton University Press.

Funkenstein, Amos. 1993. Perceptions of Jewish History. Berkeley, CA: University of California Press.

Gedi, Noa and Yigal Elam. 1996. "Collective Memory-What Is It?" History and Memory 8:30-50.

Giesen, Bernhard. 2004. Triumph and Trauma. Boulder, CO: Paradigm Publishers.

Gorn, Elliott J. 2000. "Distinguishing Between Memory and the Past." Chronicle of Higher Education, April 28, p.B5.

Griswold, Wendy. 1987a. "A Methodological Framework for the Sociology of Culture.” Pp. 1-35 in Sociological Methodology, vol. 17, edited by Clifford Clogg. Washington, DC: American Sociological Association.

___ . 1987b. "The Fabrication of Literary Meaning: Literary Interpretation in the United States, Great Britain, and the West Indies." American Journal of Sociology 92:1077-117.

Halbwachs, Maurice. [1925] 1952. Les Cadres Sociaux de la Mémoire. Paris, France: Presses Universitaires de France.

—. 1941. La Topographie Légendaire des évangiles en Sainte Terre. Paris, France: Presses Universitaires de France.

[1950] 1980. The Collective Memory, edited by Mary Douglas. New York: Harper and Row. Homans, George C. 1964. "Bringing Men Back In." American Sociological Review 29:809-18.
Jauss, Hans Robert.1982. Toward an Aesthetic of Reception. Minneapolis, MN: University of Minnesota Press.

Jordan, Winthrop D., Miriam Greenblatt, and John S. Bowes. 1985. The Americans. New York: McDougal, Littell.

Kammen, Michael. 1997. In the Past Lane: Historical Perspectives on American Culture. New York: Oxford University Press.

Kansteiner, Wulf. 2002. "Finding Meaning in Memory: A Methodological Critique of Collective Memory Studies." History and Theory 41:179-97.

Karsten, Peter. 1978. Patriot-Heroes in England and America: Political Symbolism and Changing Values over Three Centuries. Madison, WI: University of Wisconsin Press.

Klapp, Orrin. 1962. Heroes, Villains, and Fools: The Changing American Character. Englewood Cliffs, NJ: Prentice-Hall.

Klein, Kerwin Lee. 2000. "On the Emergence of Memory in Historical Discourse." Representations 69:127-50.

Lerner, Robert, Althea K. Nagai, and Stanley Rothman. 1995. Molding the Good Citizen: The Politics of High School History Texts. Westport, CT: Praeger.

Lindgren, James and Steven Calabresi. 2001. "Rating the Presidents of the United States, 1789-2000: A Survey of Scholars in Political Science, History, and Law." Constitutional Commentary 18: 583-605.

Lipset, Seymour M. 1989. Continental Divide: The Values and Institutions of the United States and Canada. Washington, DC: Canadian-American Committee.

1996. American Exceptionalism: $A$ Double-Edged Sword. New York: W.W. Norton.

Lowenthal, David. 1996. Possessed by the Past: The Heritage Crusade and the Spoils of History. New York: Free Press.

Mannheim, Karl. [1928] 1952. "The Problem of Generations." Pp. 276-320 in Essays on the Sociology of Knowledge, edited by Paul Kecskemeti. London: Routledge and Kegan Paul.

Markham, Edwin. [1911] 1970. "Lincoln, The Man of the People.” Pp.13-15 in The Praise of Lincoln, edited by A. Dallas Williams. Freeport, NY: Books for Libraries.

McFeely, William S. 1983. "The Civil War's Lure." New York Times, July 4, p. 19.

Murray, Robert K. and Tim H. Blessing. 1988. Greatness in the White House: Rating the Presidents, Washington through Carter. University Park, PA: Pennsylvania State University Press.

Nora, Pierre. 1996. Realms of Memory, 3 vols. New York: Columbia University Press.

Olick, Jeffrey K. 1999. "Collective Memory: The Two Cultures.” Sociological Theory 17:333-48. 
Peterson, Merrill. 1994. Abraham Lincoln in American Memory. New York: Oxford University Press.

Platt, Nathaniel and Muriel Jean Drummond. 1966. Our Nation From Its Creation. Englewood Cliffs, NJ: Prentice-Hall, Inc.

Potter, David M. 1948. The Lincoln Theme and American National Historiography. Oxford, England: Clarendon Press

Prager, Jeffrey. 2001. "Psychology of Collective Memory." Pp. 2223-27 in International Encyclopedia of the Social and Behavioral Sciences, edited by Neil J. Smelser and Paul B. Baltes. Oxford, England: Elsevier.

Radway, Janice. 1984. Reading the Romance: Women, Patriarchy, and Popular Literature. Chapel Hill, NC: University of North Carolina Press.

- 1997. A Feeling for Books: The Book-of-the-Month Club, Literary Taste, and Middle-Class Desire. Chapel Hill, NC: University of North Carolina Press.

Rossiter, Clinton. 1960. The American Presidency. New York: New American Library.

Rhea, Joseph T. 1997. Race Pride and the American Identity. Cambridge, MA: Harvard University Press.

Schlesinger, Arthur Jr. 1997. "Rating the Presidents: Washington to Clinton." Political Science Quarterly 112: 179-90.

Schudson, Michael. 1989. "How Culture Works: Perspectives from Media on the Efficacy of Symbols." Theory and Society 18:153-80.

. 1994. Watergate in American Memory. New York: Basic.

. 1996. "Dynamics of Distortion in Collective Memory." In How Minds, Brains, and Societies Remember the Past, edited by Daniel Schacter. Cambridge: Harvard University Press.

Schuman, Howard. 2003. "Clifford Geertz and the Interpretive Attitude Survey." Newsletter of the Culture Section of the American Sociological Association 17:1; 7-8.

Schuman, Howard and Jacqueline Scott. 1989. "Generations and Collective Memories." American Sociological Review 54:359-81.

Schuman, Howard, Barry Schwartz, and Hannah D'Arcy. 2005. "Elite Revisionist and Popular Beliefs: Christopher Columbus, Hero or Villain?" Public Opinion Quarterly 69:2-29.

Schuman, Howard, Charlotte Steeh, Lawrence Bobo, and Maria Krysan. 1997. Racial Attitudes in America: Trends and Interpretations. Cambridge, MA: Harvard University Press.

Schutz, Alfred. 1970. On Phenomenology and Social Relations, edited by Helmut R. Wagner. Chicago, IL: University of Chicago Press.

Schwartz, Barry. 2000. Abraham Lincoln and the
Forge of American Memory. Chicago, IL: University of Chicago Press. 2005. "Lincoln in the Depression." Unpublished manuscript.

Schwartz, Melvin and John R. O’Connor. 1986. Exploring American History. New York: Globe.

Sellers, Charles G., Henry Mayer, Edward L. Paynter, Alexander Saxton, Neil L. Schumsky, and Kent Smith. 1975. As It Happened: A History of the United States. New York: McGraw Hill.

Sewall, Gilbert T. 2001. History Textbooks at the New Century: A Report of the American Textbook Council. New York: American Textbook Council.

Sinkler, George. 1971. The Racial Attitudes of American Presidents. Garden City, NY: Doubleday.

Skrentny, John D. 2002. The Minority Rights Revolution. Cambridge, MA: Harvard University Press.

Smith, Rogers M. 2003. Stories of Peoplehood: The Politics and Morals of Political Membership. Cambridge, England: Cambridge University Press.

Snyder, Phil L., ed. 1958. Detachment and the Writing of History: Essays and Letters of Carl L. Becker. Westport, CT: Greenwood.

Swidler, Ann. 2001. Talk of Love: How Culture Matters. Chicago, IL: University of Chicago Press.

Terdiman, Richard.1993. Present Past: Modernity and the Memory Crisis. Ithaca, NY: Cornell University Press.

Thompson, Michael, Richard Ellis, and Aaron Wildavsky. 1990. Cultural Theory. Boulder, CO: Westview.

U.S. Abraham Lincoln Bicentennial Commission. 2004. Interim Report: June 2004. Washington, DC: U.S. Government Printing Office.

U.S. Bureau of the Census. 1975. Historical Statistics of the United States: Colonial Times to 1970. Washington, DC: U.S. Government Printing Office.

U.S. Bureau of the Census. 1990. Statistical Abstracts of the United States. Washington, DC: U.S. Government Printing Office.

Warner, Lloyd. 1959. The Living and the Dead. New Haven, CT: Yale University Press.

Wector, Dixon. 1941. The Hero in America: A Chronicle of Hero Worship. New York: C. Scribner's Sons.

Wertsch, James V. 2002. Voices of Collective Remembering. Cambridge, England: Cambridge University Press.

Wiencek, Henry. 2003. An Imperfect God: George Washington, His Slaves, and the Creation of America. New York: Farrar Strauss \& Giroux.

Wilder, Howard B., Robert P. Ludlum, and Harriett McCune Brown. 1966. This is America's Story. Boston, MA: Houghton Mifflin Company.

Wills, Garry. 1992. Lincoln at Gettysburg: The Words 
That Remade America. New York: Simon \& Schuster.

Wuthnow, Robert. 1987. Meaning and Moral Order: Explorations in Cultural Analysis. Berkeley, CA: University of California Press.

Yerushalmi, Yosef H. 1989. Zakhor: Jewish History and Jewish Memory. Seattle, WA: University of Washington Press.
Zelinsky, Wilbur. 1988. Nation Into State: The Shifting Symbolic Foundations of American Nationalism. Chapel Hill, NC: University of North Carolina Press.

Zerubavel, Eviatar. 2003. Time Maps: Collective Memory and the Social Shape of the Past. Chicago, IL: University of Chicago Press. 